\title{
NEW ORIBATOID MITES
}

\author{
By Arthur Paul Jacot. \\ Shantung Christian University.
}

In working over various collections and a revision of the Phthiracaridæ of the northeastern states, the following forms were found to be undescribed:

\section{From the Territory of HawaiI:}

\section{Indotritia subgen. nov. (Euphthiracarus)}

Related to genera Tritia, Euphthiracarus, Acrotritia, Oribotritia, but with bristles of aspis very short, the posterior ones closer to each other than to pseudostigmata and between them, median bristles near edge of aspis and close to pseudostigmata, lateral carina usually well developed; abdomen usually rounded (barely pointed) behind; anal plates with long median blades, usually with bristle at their base; lateral plates with at least two pairs of anterior bristles and three pairs of posterior bristles.

Type:-Tritia krakatauensis Sellnick (Treubia, vol. 5 (1924), pp. 372-373, figs. 1-3).

\section{E. (Indotritia) bryani sp. $n$.}

Aspis from side with postero-median depression, lateral carina not strongly developed; pseudostigmatic organ rather short, blade-like; abdomen similar to that of type, bristles short; venter rather broad, lateral plates with two pairs of anterior bristles and three pairs of posterior bristles, anal plates with basal bristles only.

Type locality:- "Wilkes Id.," Wake Island, under stones; Aug. 2, 1923; coll. by E. H. Bryan, (Tanager Expedition), about 24 adults, no. BBM07T1 and BBM07T2. Cotypes in Bernice Bishop Museum, Honolulu and Museum of Comparative Zoölogy respectively. 


\section{E. (Indotritia) hawaiiensis sp. n.}

Aspis with median carina, lateral carina distinct; pseudostigmatic organ very short and fine; abdomen similar to that of T. javensis Sellnick (1925), bristles rather long and stout; lateral plates with two pairs of anterior bristles, anal plates with two pairs of bristles.

Type locality:-Kaala Mts., Oahu; April 1892; coll. by R. C. L. Perkins, 5 adults, no. BBM18P. Cotypes in Bernice Bishop Museum.

Galumna swezeyi sp. n.

Large $(.75 \times .95 \mathrm{~mm}$.) lamellæ thick; rostral bristles close to edge of lamellæ, long, faintly barbed on outer edge; lamellar bristles very much included, long, tips almost meeting, strongly barbed; interlamellar bristles long, stout; pseudostigmatic organs short, with oval to obovate head; pteromorphal groove partially filled by an area porosa; areæ porosæ mesonoticæ large, roundoval, far down on sides; median pore large; paramesial bristles midway between apertures. Color amber yellow.

Type locality:-Kuliouou, Oahu; March 5, 1920; coll. by O H. Swezey, 2 specimens, nos. SPES11S1 and SPES11S2. Cotypes at Sugar Planters' Experiment Station, Honolulu and $\mathrm{Mu}-$ seum of Comparative Zoölogy.

\section{From the States of Connecticut and New York.}

Phthiracarus olivaceus $\mathrm{sp} . \mathrm{n}$.

Size fairly large (abdomen . $42 \times .63 \mathrm{~mm}$.); aspis anteriorly depressed, posteriorly flattened, median bristles between pseudostigmata, posterior bristles inserted beneath abdomen rim; pseudostigmatic organ rod-like, distal end resembling flower stigma, only slightly dilated; abdomen somewhat long-oval, broadest behind center, posteriorly depressed, bristles heavy, of same caliber throughout, six pairs in median row; ventral bristles at suture, the posterior pair remote from each other; anal plates nearly as wide as genital, anterior lapets well developed, bristles: two marginal, three "median"; genital plates dove-tailing at posterior end, bristles; one anterior marginal, four median; color olivaceous, texture sanded. 
Type locality:-orchard, one mile west of East Village, Monroe, Conn.; lower face of old rail, soft moist spot; Aug. 22, 1927; coll. by the writer, 33 specimens, no. $2527 \mathrm{~h} 2$. Cotypes:-M. C. Z.

\section{Phthiracarus setosellus $\mathrm{sp} . \mathrm{n}$.}

Size somewhat small $(.34 \times .54 \mathrm{~mm}$.); aspis anteriorly depressed, posteriorly flattened, posterior bristles near median; pseudostigmatic organ short, scalpel-or lancet-like; abdomen rather elongate, oval, widest at center, bristles long, tapering, fine, five pairs in median row; ventral bristles at suture, the posterior pair remote from each other; anal plates as wide as as posterior end of genital plates, median bristles more lateral than in preceding; genital plate bristles: two marginal, five median, the posterior-most marginal; color pale tan; texture sanded.

Type locality:-Glen Cove, Long Is., N. Y.; from rotten wood and under bark slabs; May 8, 1920; coll. by writer, 5 specimens, no. 209h. Cotypes:-M. C. Z.

III. From Switzerland.

\section{Achipteria oudemansi sp. $n$.}

Size rather large; $.34 \times .64 \mathrm{~mm}$., thus extremely slender; lamellæ with inner distal angle more anterior than outer, as seen from above elongate ovate i. e. anterior half wider than posterior half; base of lamellar bristles close to end of lamellæ; notogaster extremely pinched together between lamellæ forming an acute angle and extending far in between them; interlamellar bristles opposite end of notogaster and inserted on the lamellæ; pseudostigmatic organ long, slenderly clavate, extending far beyond sides of pteromorphæ which are drawn out into long, slender horns, their ends turned inward almost touching the lamellae; anterior end of camerostome pointed or carinate; anterior ventral angle of pteromorphæ drawn out into a sharp corner; anal covers the diameter of one of them distant from posterior edge of ventral plate.

Type locality:-Les Rasses, St. Croix, Vaud: moss, near a wall; Aug. 10, 1927; coll. by Mr. Auguste D. Jacot, 6 specimens, no. 270301c. Cotypes in the writer's collection. 

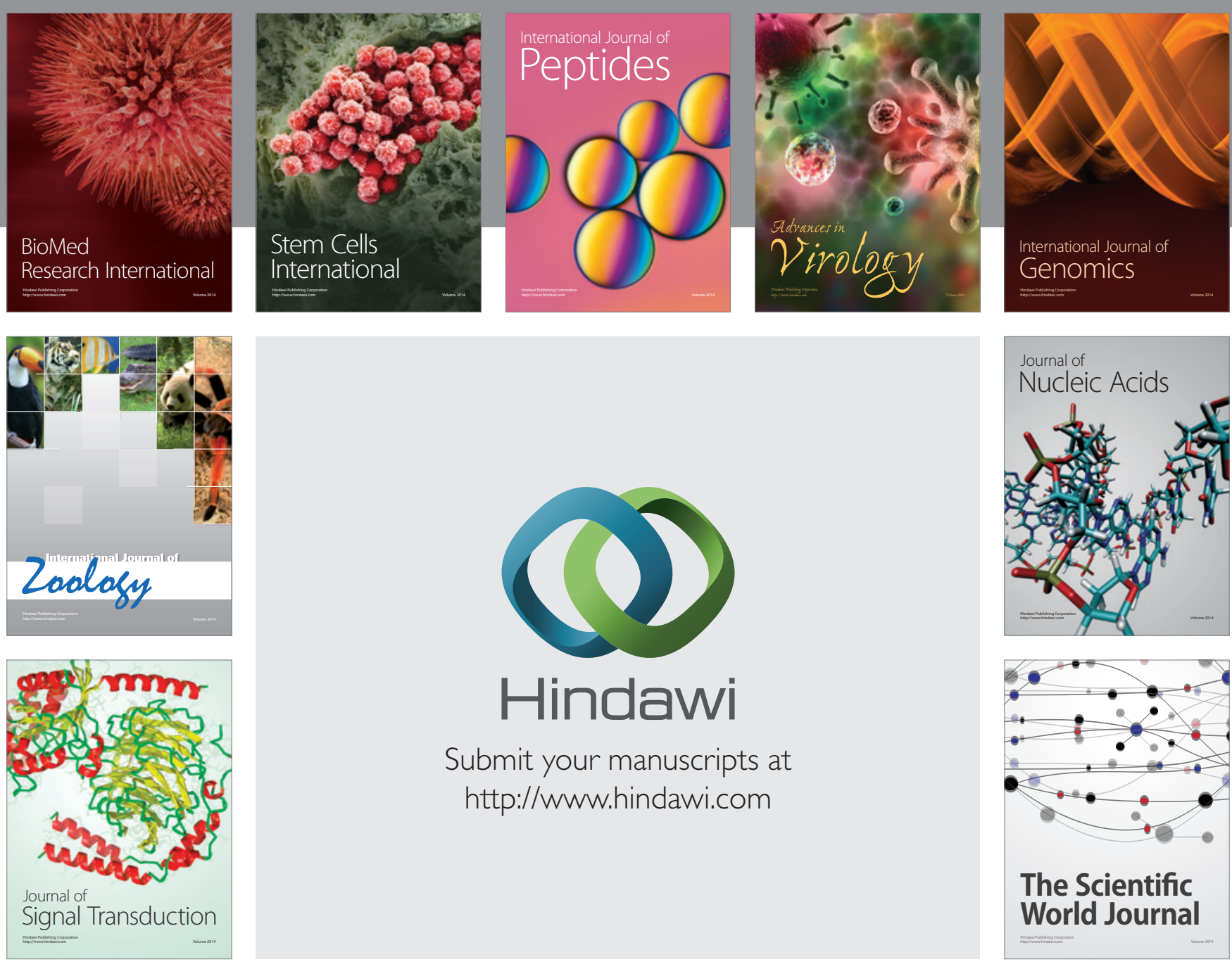

Submit your manuscripts at

http://www.hindawi.com
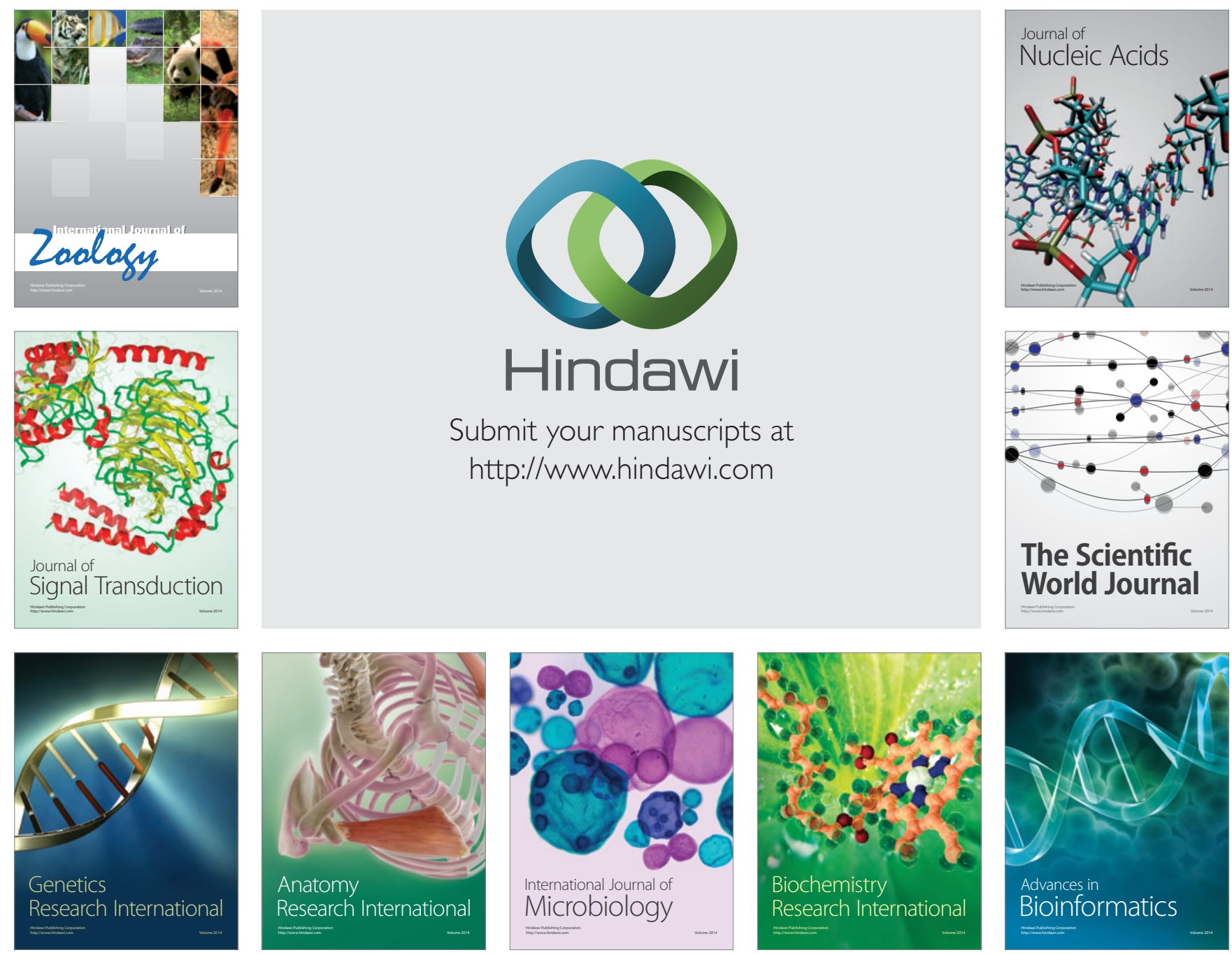

The Scientific World Journal
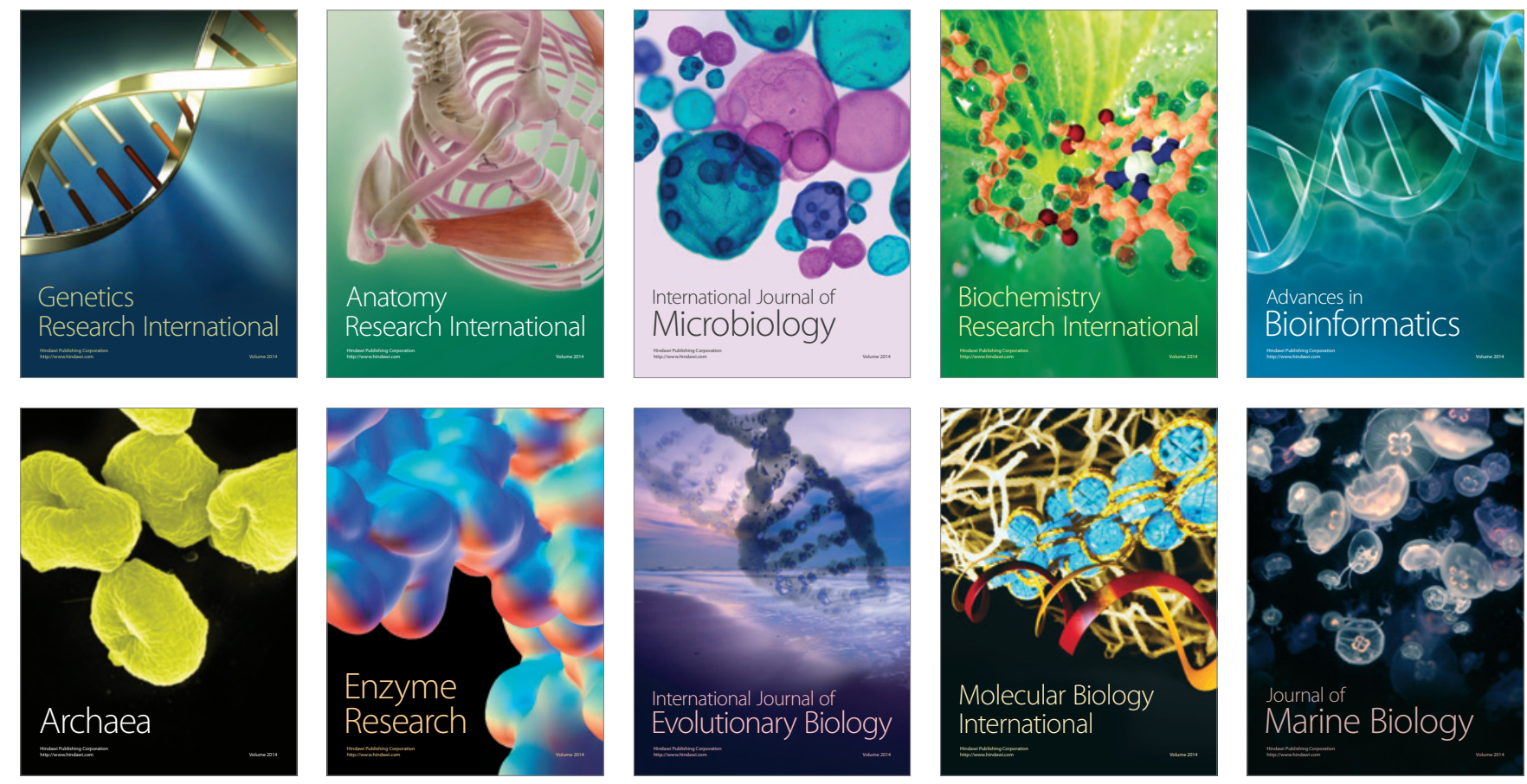